\title{
Hydrological Services of Forests and Their Compensation Initiatives
}

\author{
Hendrayanto*, Soedarsono Sudomo \\ Department of Forest Management, Faculty of Forestry, \\ Bogor Agricultural University, IPB Dramaga Campus, PO Box 168, Bogor 16680, Indonesia
}

Received November 6, 2012/Accepted March 19, 2013

\begin{abstract}
Rapid decreas of natural forest, and more frequent disaster related to the roles of forest on precipitation, flood, drought, erosion, and sedimentation as well as landslides, biodiversity, and carbon sequestration have driven initiatives to find out economic instruments for raising incentives for better land rehabilitation and forest management. Payment or compensation for hydrological services of forest is one of economic instruments that was initiated to address water availability, flood and drought, erosion, and sedimentation issues. Hydrological services offorest to some extent are still debatable, and the magnitude of the services or influences of forest varies depending on the quality of forest cover and soil, climate, and physical characteristics of land. In most cases, payment or compensation schemes of forest services to the land owner or manager that have been implemented already, do not consider the actual forest hydrological services yet. Nevertheless, those payment schemes have been driving the activities of better land and forest uses, although they are still limited to small scales relative to the whole required area to produce forest hydrological services. This article reviews the hydrological services of forests and their compensation scheme developed in Indonesia.
\end{abstract}

Keywords: forest, hydrological services, payment, compensation for environmental services

*Correspondence author, email: hendrayanto@gmail.com, telp/fax: +62-812-808-4552

\section{Introduction}

Forest is believed to have important roles in controlling hydrological cycle leading to a reduction in surface run-off, erosion, flood and an increase in low flow during drought. Those important roles of forest cover on water related phenomena and climate are appreciated undoubtedly by ancients, and up to know, by the common people (Lee 1980). Decreasing forest cover and more frequent disaster related to precipitation, flood, drought, landslides, and river sedimentation strengthen arguments for the importance of forest.

Many of the early concepts of forest roles on water related phenomena were intuitive, based on legends originally, and some were proved not always true (Lee 1980; Bruijnzeel 2004). The most persistent misconceptions are that forest increases local precipitation, forest reduces the impact of raindrops under the canopy, forest prevents disastrous floods, and forest conserves water for streamflow during periods of drought (Lee 1980; Bruijnzeel 2004). Cutting forest would supposedly decrease gross precipitation, and cause the drying up of springs and streams (Lal 1987). The role of forests, their impact on precipitation, water yield, and the hydrologic cycle more generally remain debatable (Andre'assian 2004; Ellison et al. 2012). Under this situation, reforestation and afforestation are still believed to be the best way to improve the water yield.

Rapid decrease in natural forest promotes the initiatives to find out economic instruments for creating incentives for better forest management and land rehabilitation. Payment or compensation for hydrological services of forest is one of economic instruments that is initiated to address water availability, flood and drought, erosion, and sedimentation issues.

The payment or compensation scheme of hydrological forest services to the land owner or management in Indonesia mostly is not based on achievement of hydrological forest service indicators, but more based on the agreement and belief in good forest services on hydrological aspects. This paper presents the current status of forest hydrogical research and some initiatives of payments or compensation schemes development for hydrological forest services in Indonesia.

\section{Hydrological Services of Forest}

Wether or not forest increases precipitation is still hard to prove clearly. Evapotranspiration from forest is generally higher than that from shorter crops (Bosch \& Hewlett 1982; Bruijnzeel 1990; Calder 1990; Stednick 1996; Calder 1998; Ellison et al. 2012), and forest also has greater aerodynamic roughness; therefore, creating higher atmospheric humidity and moisture convergence. In such a situation, the probabilities of cloud formation and rainfall are higher (André et al. 1989; Blyth \& Dolman 1994; Pielke et al. 1998), but based on early reviewers of the subject of forests 
and rainfall, there were no significant effect of forest on precipitation (Bruijnzeel 2004). Increased percipitation due to the forest service may occur in coastal and cloud forests (Bruijnzeel 2004). The canopy of tall trees may capture atmospheric moisture, and through canopy drips, the water reaches the forest floor. The impact of land cover on the precipitation is expected to be neglected in regions with a large oceanic contribution, such as Southeast Asia and the Pacific, West Africa, the Caribbean side of Central America and northwestern South America (Bruijnzeel 2004).

Common perception of forest role on water yield is that forest increase water yield, and vice versa, deforestation decrease water yield. This perception is supported by the concept of forest ecosystem behaving as a sponge. Forest ecosystem absorbs and stores water during rainy season, and releases it during dry season. Clear cutting and deforestation withdraw the effect of sponge and diminish water yield, dries springs, and streams during dry season (Hamilton \& King 1983; Pereira 1989; Valdiya \& Bartarya 1989). Annual water yield increases as percentage of forest removal increase (Stednick 1996). But in relation to dry up streams, many opposite phenomena are reported, i.e. streams drying up in the dry season after reforestation of degraded land. Water yield is not only dependent on land cover characteristics, but also on climatic, soil, and geological characteristics, as well as geomorphology (Guo et al. 2001; Andre'assian 2004).

General trend of forest cover removal is to increase water yield and vice versa (Vertessy et al. 2001; Brown et al. 2005; Farley et al. 2005; Jackson et al. 2005; Benyon et al. 2007; Dijk \& Keenan 2007). The magnitude effect of forest removal on water yield is dependent on the percentage of coverage removal, the level of soil disturbance during forest cover removal, as well as on rainfall intensity. The increasing water yield tends to increase the sediment load, even though it is also determined by the management of land. The existences of understory, litter, mulch, and proper conservation measures are important to maintain low surface erosion (Bruijnzeel 2004).

Reforestation and soil conservation measures can reduce enhanced peak flows and storm flows associated with soil degradation, but there is no well-documented case of a corresponding increase in low flows (Bruijnzeel 2004). Deforestation that can maintain the runoff coefficient not more than 0.1 could maintain the interflow and base flow as the same as forest does but it could increase water yield through increase surface runoff (Bruijnzeel 2004). A good plant cover can generally prevent surface erosion, and a welldeveloped tree cover may also reduce shallow land sliding, but more deep-seated $(>3 \mathrm{~m})$ slides are determined rather by geology and climate (Bruijnzeel 2004).

\section{Initiatives for Forest Services Payment}

Payment for natural resources (including water) utilization is actually common payment in governmental system, i.e. through taxation system, retributions etc. Those payments are the main source of fund for national as well as regional development and expected to be allocated to maintain the sustainability of resources uses for public welfare. However, negative impacts, and disasters related to natural resources utilization are still occuring, and even tend to occur more frequently and severely. This situation suggests that the payment and allocation (budgeting) system are not effective, or may not be sufficient to support appropriate management of natural resources. Existing taxation, retribution and other traditional common payment systems for natural resources utilization more often suffer from less consideration or calculation of negative as well as positive impacts of natural resources utilization.

The concept of internalization of externalities (positive and negative) in natural resources utilization was discussed to reduce negative impacts and to utilize natural resources more efficiently. Exploration on economic instruments to maintain and develop positive externalities, such as environmental services by internalizing benefits through direct payment to the responsible parties on resources/land management or market development was initiated in 1990's (Rosa et al. 2004). Ecosystem services are the benefits people obtain from ecosystems, including provisioning services, regulating services, and cultural services such as recreational, spiritual, religious and other nonmaterial benefits (Millennium Ecosystem Assessment 2005).

The roles of forest on hydrological aspects become one of the main issues in this environmental services payment scheme, besides carbon sequestration and biodiversity. Studies on economic values of hydrological services of forest including agroforestry increases as well as the development of their payment schemes.

The payment system or scheme of hydrological forest services ideally should consider or be based on the economic values of hydrological forest services, but in practice, especially in Indonesia's case, most of payment or compensation schemes for hydrological forest services were developed based on the agreement among related parties, where the parties believed in the good roles of forests, less or without considering the economic value of hydrological forest services itself. The amount of payment or compensation is often lower than the economic value of hydrological forest services, whilst the indicators of success are not based on the hydrological indicators.

An example of implementation of payment environmental scheme that was driven by hydrological issue was payment scheme in Cidanau Watershed in Banten Province, Java Island. There were 2 main driver factors to implement the payment scheme in Cidanau Watershed. The first was the situation where water demand for domestic, industrial as well as farming uses was increasing, while on the other hand, the water supply was decreasing. There was a severe low discharge that happened in 1997 (Budhi et al. 2008). Those situations raised the awareness and concern of a big company who managed water delivery to consumer in Cilegon City. The second was the forest encroachment and conversion into farmland. Budhi et al. (2008) reported that almost $71 \%$ of the catchment was critical lands, resulted in the annual erosion of about $146 \mathrm{t} \mathrm{ha}^{-1}$ and sedimentation $479,488 \mathrm{t} \mathrm{year}^{-1}$, and decreasing discharge, where the average discharge in 2007 was about $9 \mathrm{~m}^{3} \mathrm{sec}^{-1}$ and the lowest discharge was $1.7 \mathrm{~m}^{3} \mathrm{sec}^{-1}$. Those 2 facts of critical land and low water yield raised issue that criticals lands in Cidanau Watershed causes low water yield. This issue drove the initiative to develop payment scheme for hydrological forest 
service in Cidanau Watershed.

The transaction on that payment scheme was between water user and farmers. Water user in this case was water provider company. Payment scheme development was facilitated by Communication Forum for Cidanau Watershed and multi-stakeholders institution. The company pays a certain amount of money to farmers, and the farmers are obligated to grow perennial plants or trees. The number of tress was at least 500 trees $\mathrm{ha}^{-1}$ at the end of the first year, and at least 200 trees $^{-1}{ }^{-1}$ at the end of fifth year (Budhi et al. 2008). The transaction, interms of number of payment and farmers obligation was more based on plantation costs, without or less consideration the hydrological impacts of plantation or forest development, as well as the economic value of hydrological impacts.

According to the statement (personal communication 2012) of Head of Forestry Agency of Banten Province, the number of farmers participated in this payment scheme increased, so did the payment from the company, and this scheme becomes a model for some of "Forums of Watershed Management" in other watersheds.

Other similar schemes are also implemented in other watersheds. Governments of Kuningan District and Cirebon City signed memorandum of understanding (MoU) in 2004. This MoU was developed based on facts that Drinking Water Company (PDAM) owned by Cirebon City Government utilized water from a spring located in Kuningan District region. Both governments agreed that Cirebon Government as water user would allocate budget as compensation to Kuningan District for managing the environment of springs to maintain the appropriate water yield of springs used by PDAM Cirebon City.

The difference from the payment scheme in Cidanau Watershed is in the method of determining of payment amount. The amount of payment or compensation in Kuningan-Cirebon Government Payment Scheme was determined by considering the value of water. In this case, the value of water was determined by using raw water price, i.e. the price of water before processing and the volume of water utilized by PDAM-Cirebon City. The amount of payment for the first year was settled on Rp1.75 billion. That was equal to the price of water per cubic meter of Rp 65 ( \pm US $\$ 0.68$ cent; 1 US $\$=\mathrm{Rp} 9,500)$. This value was close to the average water value calculated by considering forest management cost of Perhutani and Forestry Agency of Kuningan District. Perhutani calculated the water price of about Rp76 $\mathrm{m}^{-3}$ and Forestry Agency of Kuningan District was about Rp45 $\mathrm{m}^{-3}$ (Sumarman 2006). The difference was due to the difference in determining forest management costs.

Kuningan District Government received payment and redistributed to district government office for overall management fund (62.5\%), Forestry and Estate Agency of Kuningan District for operational fund to conserve forest in Ciremai Mountain (30\%), and for villages related to catchment area of Paniis Springs $(7.5 \%)$ as the source of drinking water of Cirebon City (Sumarman 2006). These funds principally must be utilized for maintaining and rehabilitating the catchment area. Hydrological indicators are still less considered in this agreement.

People of Lombok Island also have been implementing this kind of payment scheme. Initiatives were started in 2002-2003, and the program was named as the Payment for Watershed Services (PWS). The issue as a basis to develop the payment scheme was the same, i.e. a lot of springs were drying or disappeared, which were believed due to forest degradation.

The amount of payment in this scheme was determined through a long process, using the approach of willingness to pay (WTP), and finally, the people in Mataram City agreed

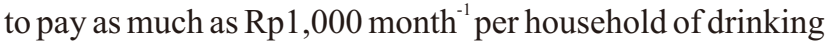
water utilization, and Rp1,500 month $^{-1}$ per company for industry's needs. Payment collection was started in 2005. Legal aspects of this payment were developed in 2006, and the independent, multi-stakeholder institution (IMP) was established in 2009 with main obligation to manage conservation funds, audit fund allocation and uses, and conduct management conflict related to PWS (LPMEquator 2011).

LPM-Equator (2011) explained that collected funds were allocated for IMP management (25\%) and Conservation Farmer Group (CFG) 75\%. The total amount received by $\mathrm{CFG}$ was allocated for restoration program $(85 \%)$ and the rest (15\%), for institutional development and creating alternative economic activities. Up to 2011, there are 3 CFGs funded by this scheme (PWS). Payment scheme in Lombok (PWS) is the same as payment schemes in Cidanau Watershed and Paniis Spring Catchment in Kuningan-Cirebon, i.e. there is no indicators or guaranty related to improvement of forest services in water yield.

Reward for Use of and Shared investment in Pro-poor Environmental Services (RUPES) program introduces different scheme of compensation as described previously. A program implemented in Sumberjaya Lampung paid or rewarded farmer involved in a group named "RiverCre group" who was able to reduce sedimentation in the river succesfully. The amount of payment is depending on the rate of sediment reduction ranging from US\$250 for $10 \%$ reduction up to US\$ 1000 for $30 \%$ and more sediment reduction (Leimona 2009). This scheme of payment is different from the 3 other payment schemes, in which payment is based on outcome i.e. water quality of the soil and water conservation measures, while the other schemes are still based on output i.e. number of planted trees or agreed existing conditions, without monitoring the outcome (water yield). Those 4 payment schemes are driven by hydrological forest services issue which are relatively more popular then many other similar initiatives conducted in Indonesia. Similarities and differences among 4 those payment schemes are presented in Table 1.

\section{Payment Schemes, Hydrological Impact and Forest Development}

Payment or compensation schemes developed in Indonesia as described earlier were initiated and developed based on hydrological forest services issue, i.e. the role of forest on water yield issues, or in other words, the payment or compensation was aimed to pay or compensate the positive impacts of land, forest management to hydrological function of watershed, especially good water yield. The level 
Table 1 Similarities and differences among 4 payment schemes

\begin{tabular}{|c|c|c|c|c|}
\hline Location & Driven issues & $\begin{array}{l}\text { Payment amount } \\
\text { determination approaches }\end{array}$ & $\begin{array}{l}\text { Performance } \\
\text { indicators }\end{array}$ & $\begin{array}{l}\text { Monitoring } \\
\text { hydrological } \\
\text { indicators }\end{array}$ \\
\hline $\begin{array}{l}\text { Cidanau } \\
\text { Watershed }\end{array}$ & $\begin{array}{l}\text { Critical land-low } \\
\text { discharge }\end{array}$ & Land rehabilitation cost & Number of trees ha ${ }^{-1}$ & Do not conducted yet \\
\hline $\begin{array}{l}\text { Kuningan- } \\
\text { Cirebon } \\
\text { Districts }\end{array}$ & $\begin{array}{l}\text { Spring quantity and } \\
\text { quality -forest management }\end{array}$ & Raw water price & $\begin{array}{l}\text { Progress of land-forest } \\
\text { conservation }\end{array}$ & Do not conducted yet \\
\hline Lombok Island & $\begin{array}{l}\text { Water yield-forest } \\
\text { degradation }\end{array}$ & Willingness to pay (WTP) & $\begin{array}{l}\text { Progress of land-forest } \\
\text { conservation }\end{array}$ & Do not conducted yet \\
\hline $\begin{array}{l}\text { Sumberjaya } \\
\text { Lampung }\end{array}$ & $\begin{array}{l}\text { Sediment load of river-soil } \\
\text { conservation measures }\end{array}$ & Rate of sediment reduction & $\begin{array}{l}\text { Sediment load } \\
\text { reduction }\end{array}$ & Sediment load \\
\hline
\end{tabular}

of payment scheme development is still limited to small area relative to whole catchment area that influences water yield, the responsible actors are limited to upper part of watershed, and the beneficiaries of water yield who pay are limited to big (drinking water) companies. The payment schemes mostly have not yet employed the performance indicators of land and forest management related water yield aspects, but have been focused more on the performance indicators of forest development.

Those payment schemes give benefit to farmers who involved in the payment schemes. Farmers earn income from cash payment as well as from the yields of trees such as fruits and other non-timber products. The schemes, potentially be able to motivate farmers to develop forest plantation and perhaps will be able to save the existing natural forest, and furthermore, to give benefit to public through the role of forest on carbon sequestration to reduce $\mathrm{CO}_{2}$ in the atmosphere. Nevertheless, the impact of those payment schemes on hydrological aspects as the initial and main objectives of payment schemes are still questioned, because measurement, monitoring of hydrological impacts of planting, and other related activities are not involved yet in the payment schemes, while the impacts of afforestation, reforestation on hydrological aspects are uncertain, depending on intensity of activities, climate, and land characteristics as mentioned before in the section of "hydrological services of forest".

The impact of land rehabilitation through tree planting (reforestation and afforestation) and soil conservation measures in relation to water yield should be paid attention, that is in a certain period, it potentially results in something beyond our expectations. As mentioned before, reforestation, afforestation, and soil conservation measures reduce peak flows and storm flows, but there is no well-documented case of a corresponding increase in low flows (Bruijnzeel 2004). It means, that land rehabilitation through reforestation as well as afforestation will reduce average water yield, and perhaps it also will not increase low flow during dry seasons, at least at a certain period.

Reduction in peak flow means reduction in run-off during rainy season, and it reduces the potential of flood, and may also increase water quality. The impact of rehabilitation should consider the area of reforestation, afforestation, and or soil conservation measures relative to area of catchment area of concern and also the quality of those measures related to hydrological aspects, such as vegetation density, level of soil disturbance, quality of terraces, etc. If the area of reforestation, afforestation, and or soil conservation measures is relatively small to catchment area of interest, it may not significantly influence water yield, as well as the quality of measures. Less density of vegetation, absence of litter or cover crops, soil disturbance, and unappropriate constructions of teraces will have no or less impact on water yield, even the opposite results that are worse then expectation and an increase in soil surface erosion are possible.

The impacts of reforestation, afforestation, and soil conservation measures on low flow are less scientifically proven, some evidences occur such as in Sikka Catchment in Flores, where the dried-up spring restored after reforestation (Bruijnzeel 2004). The same phenomenon also occurred in a small catchment in Megamendung, Bogor (Istiawan 2012, personal communication and field observation). All those things mean that the impact of reforestation, afforestation and soil conservation measures on low flow are uncertain. Factors other then tree planting and soil conservation measures might play more important roles.

Considering the uncertainty, wide variation in impact magnitudes of reforestation, afforestation, and soil conservation measures on hydrological aspects, thereby, monitoring on hydrological aspects, such as discharge, sediment load of the stream is necessary, and important to be done to know whether or not the impact is positive, and to be considered to be involved in payment schemes. It is important in order to avoid and anticipate negative reaction or complaints from water users who pay the expected benefit of better hydrological aspects.

Forest development driven by initiatives and implementation of payment or compensation for hydrological forest services, actually produces other benefits, such as fruit production or other products resulted from unharvested trees, carbon sequestration, increasing biodiversity, etc. Some benefits are public benefits, therefore, public should also pay the benefit. The 
government as a public entity should reasonably pay more attention to generate and allocate fund from public for awarding, compensating or other kind of incentive to the parties who produce public benefit. Public participation through government and other schemes incorporated in payment or compensation schemes for hydrological forest services is possible to extend the activities toward more effective results to address the hydrological forest issues.

Payment or compensation scheme for hydrological forest services as initiatives should be appreciated. But it needs continous improvement to empower payment scheme and implementation management institution toward more effective payment schemes and more accountable implementation management institution.

\section{Conclusion}

Hydrological forest services payment schemes were initiated and developed under situation of uncertainty of hydrological forest services, and wide range magnitude of forest development impacts on hydrological aspects, while monitoring hydrological aspects are not included in most hydrological forest service payment schemes. Monitoring hydrological performance indicators are needed to be involved in hydrological forest service payment schemes to avoid and anticipate negative reaction or complaints from water users who pay the expected benefit. Regardless of the lacks of hydrological aspects of the payment schemes, the developed payments schemes have motivated farmers, and raised awareness of the people, especially farmers and water consumer involved in the payment schemes in developing new forest and maintaining existing good forest; and in fact, the established new forest, and maintained existing good forest driven by these payment schemes produce environmental services benefit by public. Therefore, the government as a public entity should reasonably pay more attention to generating and allocating fund from public for awarding, compensating or other kind of incentives, and those are involved in the payment schemes.

\section{References}

André J-C et al. 1989. Impact of forests on mesoscale meteorology. Philosophical Transactions Royal Society 324:407-422. http://dx.doi.org/10.1098/rstb.1989. $\underline{0055}$.

Andre'assian V. 2004. Waters and forests: from historical controversy to scientific debate. Journal of Hydrology 291:1-27. http://dx.doi.org/10.1016/j.jhydrol.2003.12. $\underline{015}$.

Benyon R, England J, Eastham J, Polglase P, White D. 2007. Tree water use in forestry compared to other dry-land agricultural crops in the Victorian context: report prepared for the department of Primary Industries Victoria to promote scientific knowledge In This Area. Ensis Technical Report 159. pp50.

Blyth EM, Dolman AJ. 1994. The effect of forest on mesoscale rainfall: an example from hapex-mobilhy. Journal of Applied Meteorology 33:445-454. http://dx. doi.org/10.1175/1520-0450(1994)033<0445: TEOFOM $>2.0 . \mathrm{CO} ; 2$

Bosch JM, Hewlett JD. 1982. A review of catchment experiments to determine the effect of vegetation changes on water yield and evapotranspiration. Journal of Hydrology 55: 3-23. http://dx.doi.org/10.1016/00221694(82)90117-2.

Brown AE, Zhang L, McMahon TA, Western AW, Vertessy RA. 2005. A review of paired catchment studies for determining changes in water yield resulting from alterations in vegetation. Journal of Hydrology 310:2861. http://dx.doi.org/10.1016/j.jhydrol.2004.12.010.

Bruijnzeel LA. 1990. Hydrology of Moist Tropical Forest and effect of Conversion. A State of Knowledge Review. Paris: UNESCO International Hydrological Programme.

Bruijnzeel LA. 2004. Hydrological functions of tropical forests: not seeing the soil for the trees? Agriculture, Ecosystems and Environment 104:185-228. http://dx. doi.org/10.1016/j.agee.2004.01.015.

Budhi GS, Kuswanto SA, Iqbal M. 2008. Concept and implementation of pes program in the cidanau watershed: a lesson learned for futer environmental policy. Analisis Kebijakan Pertanian 6:37-55.

Calder IR. 1990. Evaporation in the Uplands. Wiley, Chichester. pp148.

Calder IR. 1998. Water use by forests, limits and controls. Tree Physiology 18:625-631. http://dx.doi.org/10. 1093/treephys/18.8-9.625.

Dijk AIJM van, Keenan RJ. 2007. Planted forests and water in perspective. Forest Ecology and Management 251:19. http://dx.doi.org/10.1016/j.foreco.2007.06.010.

Ellison D, Futter MN, Bishop K. 2012. On the forest coverwater yield debate: from demand to supply side thinking. Global Change Biology18:806-820. http://dx. doi.org/10.1111/j.1365-2486.2011.02589.x.

Farley KA, Jobba'gy EG, Jackson RB. 2005. Effects of afforestation on water yield: a global synthesis with implications for policy. Global Change Biology 11:1565-1576. http://dx.doi.org/10.1111/j.1365-2486. 2005.01011.x.

Guo Z, Xiao X, Gan Y, Zheng Y. 2001. Ecosystem functions, services and their values-a case study in Xingshan county of China. Ecological Economics 38:141-154. http://dx.doi.org/10.1016/S0921-8009(01)00154-9.

Hamilton LS, King PN. 1983. Tropical Forested Watersheds. Hydrologic and Soils Response to Major Uses or Conversions. Boulder:Westview Press. pp 168. 
Jackson RB et al. 2005. Trading water for carbon with biological carbon sequestration. Science 310:19441947. http://dx.doi.org/10.1126/science.1119282.

Lal R. 1987. Tropical Ecology and Physical Edaphology. New York: Wiley.

Lee R. 1980. Forest Hydrology. New York: Columbia University Press.

Leimona B. 2009. Can rewards for environmental services benefit the poor? Lessons from asia. International Journal of The Commons. 3(1):1-14.

LPM-Equtor. 2011. Report on Payment for Environmental Service (PES) Scheme Development Process. (in Indonesian). Report-C. Bogor: LPM-Equator.

[MEA] Millennium Ecosystem Assessment. 2005. Ecosystems and Human Well-Being: General Synthesis. Washington: Island Press and World Resources Institute.

Pereira HC. 1989. Policy and Practice of Water Management in Tropical Areas. Boulder: Westview Press. pp 237.

Pielke RA et al. 1998. Interactions between the atmosphere and terrestrial ecosystems: influence on weather and climate. Global Change Biology 4:461-475. http://dx. doi.org/10.1046/j.1365-2486.1998.t01-1-00176.x.

Rosa H, Barry D, Kandel S, Dimas L. 2004. Compensation for Environmental Services and Rural Communities: Lessons from the Americas. Working Paper 98. Massachusetts: Political Economy Research Institute, University of Massachusetts.

Sumarman. 2006. Analysis of raw water compensation for drinking water, from Cirebon City government to Kuningan District government. (in Indonesian) [thesis]. Semarang: Graduate Program of Diponegoro University.

Stednick JD. 1996. Monitoring the effects of timber harvest on annual water yield. Journal of Hydrology. 176: 7995. http://dx.doi.org/10.1016/0022-1694(95)02780-7.

Valdiya KS, Bartarya SK. 1989. Diminishing discharges of mountain springs in a part of the Kumaun Himalaya. Current science 58:417-426.

Vertessy RA, Watson FGR, O'Sullivan SK. 2001. Factors determining relations between stand age and catchment water balance in mountain ash forests. Forest Ecology and Management 143:13-26. http://dx.doi.org/10. 1016/S0378-1127(00)00501-6. 